\title{
MICROBIAL STATUS OF RHIZOSPHERE OF GALEGA ORIENTALIS PLANTS INFECTED WITH PHYTOPATHOGENS AND TREATED WITH NANOCHELATES
}

\author{
H.B. Huliaieva ${ }^{1}$, I.P. Tokovenko' ${ }^{1}$ L.A. Pasichnyk ${ }^{1}$, \\ V.P. Patyka', S.M. Horbatiuk ${ }^{2}$
}

\author{
${ }^{1}$ Zabolotny Institute of Microbiology and Virology, NAS of Ukraine, \\ 154 Acad. Zabolotny Str., Kyiv, 03143, Ukraine \\ ${ }^{2}$ National Pirogov Memorial Medical University, \\ 56 Pirogova Str., Vinnytsya, 21018, Ukraine \\ e-mail:ab_k@ukr.net
}

\begin{abstract}
It is known that the ratio of the main groups of microorganisms in the microbiocenosis form the biological fertility of the soil. In this regard, it is necessary to take into account the influence of biologically active substances, including nanoparticles and their derivatives, used in crop production, on the composition of soil microbiota and its biodiversity. The aim of this study was to investigate the effect of Galega orientalis plants inoculation with phytopathogenic microorganisms and foliar treatment of plants with nanochelates on the total amount of microbial groups in rhizosphere of Galega orientalis. Methods. Acholeplasma laidlawii var. granulum 118 UCM BM-34 was cultivated in the liquid nutrient medium CM IMV-72 (pH 7.8) in thermostat at $32{ }^{\circ} \mathrm{C}$ for 72 hours. Pseudomonas syringae pv. atrofaciens D13 was cultivated on potato agar in thermostat at $26-28{ }^{\circ} \mathrm{C}$. For artificial infection a bacterial suspension with a concentration of $1 \times 10^{9} \mathrm{CFU} / \mathrm{mL}$ according to the turbidity standard was prepared. Galega orientalis plants were inoculated with phytopathogenic strains of microorganisms by subepidermal injection into the stem. The total count of microbial groups in the samples was performed by the method of plating on selective media, the result was expressed in colony-forming units (CFU). For statistical processing of data, calculations of the arithmetic mean and its standard error were performed. Results. It was found that the total amount of microorganisms, the number of actinomycetes and oligotrophic microorganisms increased and the number of micromycetes decreased in the rhizosphere of Galega orientalis plants infected with phytoplasma. In contrast to phytoplasma infected plants, the number of aerobic nitrogenfixing bacteria in the rhizosphere increased in plants infected with P. syringae pv. atrofaciens D13. Foliar treatment of Galega orientalis plants with nanochelate solutions had varying influence on the composition of microbial groups. The total amount of aerobic nitrogen-fixing bacteria increased after foliar treatment with nanochelates in the next order: $V>G e>S e$, and the total amount of actinomycetes increased after foliar treatment in the next order: $S e>V>G e$. The total amount of micromycetes increased in the rhizosphere of Galega orientalis after foliar treatment with Ge and Se nanochelates. It should be noted that the most significant increase in the number of oligotrophic microorganisms was observed in the rhizosphere of plants after I-Se foliar treatment. Conclusions. The number of actinomycetes, micromycetes and oligotrophic microorganisms in the rhizosphere of Galega orientalis plants infected with A. laidlawii and P. syringae increased compared to control plants; this process was associated with changes in the chemical composition of root secretions, probably due to reducing of carbohydrates and the presence of stress signal molecules. Plants infection with these pathogens had different effect on the total amount of aerobic nitrogen-fixing bacteria, the number of which increased in the rhizosphere after infection with P. syringae and decreased after infection with A. laidlawii, which may be due to the different chemical composition of the root secretions. Foliar treatment with Se, Ge and V nanochelates had the most favorable influence on the soil microbiota, causing an increase in the total amount of microbial groups, including species capable of disease development inhibiting and participating in the nutrient cycle (aerobic nitrogen-fixing bacteria, actinomycetes, micromycetes). The foliar treatment of plants with I-Se nanochelates can be considered as conditionally favorable due to a significant increase in the number of oligotrophic microorganisms, which indicates the depletion of readily available nutrients in the soil. However, the improvement of root system growth at I-Se foliar treatment of plants affected by
\end{abstract}


both phytoplasma and bacterial pathogen may be a sign of stimulation of the absorptive capacity of roots, which requires further research.

Keywords: Galega orientalis, Acholeplasma laidlawii var. granulum, Pseudomonas syringae pv. atrofaciens, nanochelates, soil microbiota.

The global degradation of land, which requires the search for effective measures for the purpose to restore the soil fertility, is one of the current problems [1-3]. In many countries of the world, the problem of soil regeneration is solved with the methods of ecological restoration, in particular with application of microbiological technologies [4-8]. It is known that the soil microbiota is quite variable in its composition, and its number and ratio are influenced by many factors, ranging from climate change to human anthropogenic activity [8]. However, the microbiota of the rhizosphere layer of the soil is quite sensitive to plant metabolism, as the root secretions of plants are a direct source of nutrition for microorganisms living in this soil layer [1]. In this regard, it is necessary to take into account the impact of new promising technologies in crop production, in particular on the basis of nanoparticles and their derivatives, on the composition of soil microbiota, that influence on biological activity and fertility of the soil [9].

The use of nanotechnology in various fields of agricultural production can minimize the chemical load on the environment [9-11]. In addition to that, the more prolonged action of nanoparticles and their compounds compared to nutrient salts should be taken into account. However, cost-effectiveness and environmental safety are important advantages of using citrates of nanoparticles (nanochelates) $[10,12]$.

Therefore, the aim of our work was to study the effect of Galega orientalis plants inoculation with phytopathogenic microorganisms and application of foliar treatment of plants with nanochelates on the total count of major groups of microorganisms in the rhizosphere of Galega orientalis.

Materials and methods. In field experiment Galega orientalis plants were grown on a plot with a total area of $50 \mathrm{~m}^{2}$, sod-podzolic soil. The experiments were performed in triplicate.

Artificial inoculation of phytoplasma Acholeplasma laidlawii var. granulum 118 UCM BM34 (causative agent of pale-green dwarfism) was performed using Clement's method (subepidermal injection into plant stem). A. laidlawii var. granulum 118 was cultivated in the liquid nutrient medium CM IMV-72 (pH 7.8) in thermostat at $32{ }^{\circ} \mathrm{C}$ for
72 hours. Pseudomonas syringae pv. atrofaciens D13 (causative agent of basal bacteriosis) was cultivated on potato agar in thermostat at $26-28{ }^{\circ} \mathrm{C}$. For artificial infection a bacterial suspension with a concentration of $1 \times 10^{9} \mathrm{CFU} / \mathrm{mL}$ according to the turbidity standard was prepared.

Foliar treatment of plants was carried out using solutions of nanochelates: Se (1\%), I-Se $(0.5 \%)$, $\mathrm{V}(0.75 \%)$ and $\mathrm{Ge}(0.75 \%)$ at the beginning of the growing season (April). The concentration of nanoparticles in the initial solution was: $\mathrm{Se}-100$ $\mathrm{mg} / \mathrm{L}$; I-Se (I - $80 \mathrm{mg} / \mathrm{L}$ and $\mathrm{Se} \leq 0.05 \mathrm{mg} / \mathrm{L}) ; \mathrm{V}-$ $31 \mathrm{mg} / \mathrm{L} ; \mathrm{Ge}-500 \mathrm{mg} / \mathrm{L}$.

Soil samples from the rhizosphere of control and inoculated plants of Galega orientalis were obtained from the experimental plots in triplicate (in July).

The total count of microbial groups in the samples was performed by the method of plating on selective media, the result was expressed in colonyforming units (CFU). The following determinations were made: 1 . The total amount of microorganisms in the soil growing on Zvyagintsev medium. 2. The total amount of aerobic nitrogen-fixing bacteria (oligotrophic, azotobacter) growing on Ashby medium. 3. The total amount of microorganisms that absorb nitrogen from mineral compounds and actinomycetes growing on starch-and-ammonia agar. 4. The total amount of microscopic fungi growing on wort agar. 5. The total amount of oligotrophic bacteria growing on starvation agar [13]. Procedure was performed in triplicate.

Sampling of plants for biometric analysis was performed in the phase of mass flowering, the beginning of seed formation. To determine the number of nodules, soil monoliths $30 \times 30 \times 40 \mathrm{~cm}$ was selected. 3 plants were taken from each repetition; the roots were washed and dried. The length of the roots and shoots of the plants were measured. Nodules were separated from the roots, their average number per plant was counted.

For statistical processing of data, calculations of the arithmetic mean and its standard error were performed.

Results. The total amount of microorganisms increased 6.4 and 1.8 times in the rhizosphere of Galega orientalis plants infected with A. laidlawii 
var. granulum 118 and $P$. syringae pv. atrofaciens D13, respectively (Fig. 1a). Moreover, the total aerobic nitrogen-fixing bacteria count in the rhizosphere of plants infected with phytoplasma decreased by $6.8 \%$, and in plants infected with bacteria, on the contrary, increased by $33.8 \%$. The total actinomycetes count in the rhizosphere

A

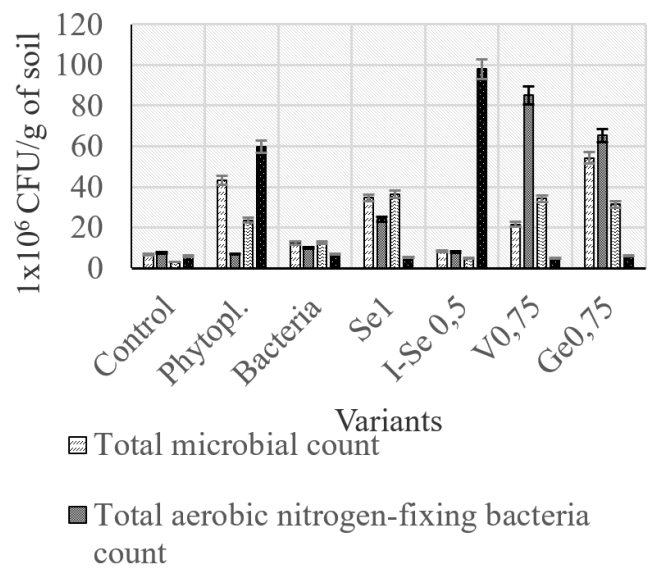

of plants infected with phytoplasma increased 7.6 times, and with bacteria - by 4 times, compared to the control (Fig. 1a). The total micromycetes count decreased in plants infected with both phytopathogens: by 52.6 and $47.4 \%$ at inoculation by phytoplasma and bacteria, respectively (Fig. 1b).
B

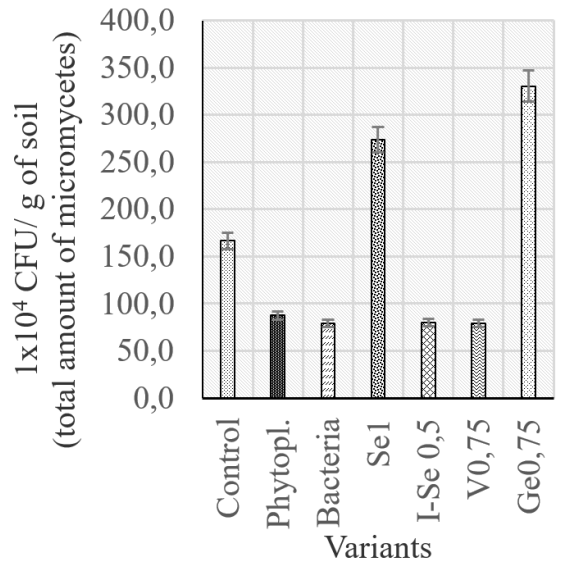

F i g. 1. The total microbial groups count in the rhizosphere of Galega orientalis plants infected with A. laidlawii var. granulum 118 and $P$. syringae pv. atrofaciens D13 and treated with nanochelates

The total amount of oligotrophic microorganisms in the rhizosphere of plants infected with phytoplasma increased 10.2 times, while in plants infected with bacteria - by $17 \%$. The number and ratio of soil microorganisms changed during the period of active growth of green mass of Galega orientalis in the variants with foliar treatment with nanochelates in comparison with the control.

Thus, the total amount of microorganisms increased in the rhizosphere of plants at foliar treatment with nanochelates in the following order: $\mathrm{Ge}>\mathrm{Se}>\mathrm{V}>\mathrm{I}-\mathrm{Se}$ (Fig. 1a). The total amount of aerobic nitrogen-fixing bacteria at foliar treatment increased in the next order: $\mathrm{V}>\mathrm{Ge}>\mathrm{Se}>\mathrm{I}$ $\mathrm{Se}$; the total amount of actinomycetes increased in the variants at foliar treatment with nanochelates in the following order: $\mathrm{Se}>\mathrm{V}>\mathrm{Ge}>\mathrm{I}-\mathrm{Se}$ (Fig. 1a).

The total micromycetes count in the rhizosphere increased in the case of foliar treatment with Ge and Se (Fig. 1b). It should be noted that the most significant increase of total oligotrophic microorganisms count was observed in the variant with I-Se foliar treatment (see Fig. 1a).

It was found that infection of Galega orientalis with phytoplasma caused significant inhibition of root system growth: its length decreased by $22.8 \%$ and the root nodule count decreased 9.2 times (Table 1).
Foliar treatment of phytoplasma infected plants with nanochelates increased root nodule count (to a greater extent $-\mathrm{Se}$ and V): $\mathrm{Se}-2.68$ times, $\mathrm{V}-$ 2.35 times, Ge - by $32.4 \%$, I-Se - by $29.1 \%$ as compared to plants without treatment (see Table 1).

The length of the roots increased under the influence of foliar treatment of plants with: Se (by $70.6 \%$ ), V (by $56.0 \%$ ), I-Se (by $20.6 \%$ ) and under the action of $\mathrm{Ge}$ - did not change in comparison with the affected plants without treatment. It was found only a tendency of shoot growth decreasing in plants infected with phytoplasma as well as treated with all nanochelates except V. Under the influence of V, the growth of Galega orientalis shoots increased by $9.4 \%$.

The root length of plants infected with $P$. syringae pv. atrofaciens D13 reduced by $24.0 \%$ compared to control, which was accompanied with significant reduction in the number of nodules on the roots. The length of the roots of bacteria-infected plants increased after foliar treatment with nanochelates I-Se (by $43.9 \%$ ), Ge (by $58.3 \%$ ), and Se (by $18.7 \%$ ) and did not change after $\mathrm{V}$ treatment. The length of shoots had tendency to decrease in bacteria-infected plants. Foliar treatment of bacteria-infected plants with $\mathrm{V}$ and Ge nanochelates caused an increase in shoot growth by 17.6 and $10.5 \%$, respectively. Foliar 
Table 1

The plant biometrics and the number of nodules on the roots of Galega orientalis plants infected with phytopathogenic microorganisms and treated with chelates of nanoparticles

\begin{tabular}{|l|c|c|c|c|c|c|}
\hline Plant biometrics & Control & A. laidlawii & $\begin{array}{c}\text { Se } 1 \%+ \\
\text { A. laidlawii }\end{array}$ & $\begin{array}{c}\text { I-Se } 0.5 \%+ \\
\text { A. laidlawii }\end{array}$ & $\begin{array}{c}\text { V } 0.75 \%+\text { Aaidlawii } \\
\text { A. }\end{array}$ & $\begin{array}{c}\text { Ge } 0.75 \%+ \\
\text { A. laidlawii }\end{array}$ \\
\hline $\begin{array}{l}\text { Height of the shoot } \\
(\mathrm{cm})\end{array}$ & $136.3 \pm 6.8$ & $135.6 \pm 6.7$ & $134.5 \pm 6.6$ & $129.0 \pm 6.5$ & $149.0 \pm 7.4$ & $129.0 \pm 6.5$ \\
\hline $\begin{array}{l}\text { Length of the root } \\
(\mathrm{cm})\end{array}$ & $18.2 \pm 0.9$ & $13.9 \pm 0.7$ & $16.5 \pm 8.2$ & $20.0 \pm 1.0$ & $13.5 \pm 0.7$ & $22.0 \pm 1.1$ \\
\hline $\begin{array}{l}\text { Root nodule count } \\
(\mathrm{pcs})\end{array}$ & $276.0 \pm 13.7$ & $30.2 \pm 1.35$ & $81.0 \pm 4.1$ & $39.0 \pm 1.9$ & $71.0 \pm 3.6$ & $40.0 \pm 2.0$ \\
\hline Plant biometrics & Control & P. syringae & $\begin{array}{c}\text { Se } 1 \%+ \\
\text { P. syringae }\end{array}$ & $\begin{array}{c}\text { I-Se } 0.5 \%+ \\
\text { P. syringae }\end{array}$ & $\begin{array}{c}\text { V } 0.75 \%+P . \\
\text { syringae }\end{array}$ & $\begin{array}{c}\text { Ge } 0.75 \%+ \\
\text { Pyringae }\end{array}$ \\
\hline $\begin{array}{l}\text { Height of the shoot } \\
(\mathrm{cm})\end{array}$ & $136.3 \pm 6.8$ & $131.7 \pm 6.6$ & $135.7 \pm 6.8$ & $141.3 \pm 7.0$ & $160.3 \pm 8.0$ & $150.7 \pm 7.5$ \\
\hline $\begin{array}{l}\text { Length of the root } \\
(\mathrm{cm})\end{array}$ & $18.2 \pm 0.9$ & $14.1 \pm 0.7$ & $24.0 \pm 1.2$ & $17.0 \pm 0.8$ & $22.0 \pm 1.1$ & $14.5 \pm 0.7$ \\
\hline $\begin{array}{l}\text { Root nodule count } \\
(\mathrm{pcs})\end{array}$ & $276.0 \pm 13.7$ & $23.4 \pm 5.1$ & $200.0 \pm 10.2$ & $65.8 \pm 3.9$ & $28.0 \pm 1.4$ & $50.0 \pm 2.6$ \\
\hline
\end{tabular}

treatment of bacteria-infected plants with Se and I-Se nanochelates did not have a significant effect on shoot growth.

Root nodule count increased in plants treated with chelates of nanoparticles compared to infected plants without treatment: Se (8.6 times), I-Se (2.8 times), Ge (2.1 times), V (by $19.7 \%$ ) (Table 1).

Thus, infection with phytoplasma and bacterial pathogen inhibited the growth of the root system, also causing a reduction in the number of nodules on the roots. Treatment of infected plants with nanochelates reduced the negative effect of infection with phytopathogens.

Thus, artificial phytoplasma infection caused a decrease in the number of total aerobic nitrogenfixing bacteria and micromycetes count, increased total actinomycetes count and significantly increased total oligotrophic microorganisms count. At the same time, a suppression of the root system growth and root nodule count were observed. Artificial infection with bacterial pathogen increased the total actinomycetes and aerobic nitrogenfixing bacteria count, less significantly increased total oligotrophic microorganisms count in plants rhizosphere, compared to phytoplasma-infected plants. Bacterial infection significantly reduced the total micromycetes count in the rhizosphere of Galega orientalis plants. Under these conditions, the growth of the root system remained at the level of control and the root nodule count decreased. It should be noted that phytoplasma infection of
Galega orientalis had more significant effect on the total count of rhizosphere microorganisms. At the same time, foliar treatment of plants with V, Ge and Se nanochelates had positive influence on the soil, improving the content of beneficial for agriculture microorganisms, including aerobic nitrogen-fixing bacteria, and positively effects on the weight of roots and root nodule count on them.

It was found that foliar treatment of phytoplasma-infected Galega orientalis plants with Se, $\mathrm{V}$ and I-Se nanochelates had positive effect on the growth of root system, and $\mathrm{V}-$ on the growth of shoots.

The positive effect of Ge, I-Se and Se treatment on root growth at bacterial infection and $\mathrm{V}$ and $\mathrm{Ge}-$ on shoot growth was observed.

Discussion. It is known that microbiocenosis is an important part of the soil, which consists of the main groups of microorganisms, the ratio of which forms its biological fertility [14, 15]. Some of the soil microorganisms have important functions in the nutrient and carbon cycles. Interactive microbial communities are formed by a variety of microorganisms, such as bacteria, viruses, micromycetes, and algae [16]. Bacteria are one of the most common groups of soil microorganisms, most of which are present in the rhizosphere layer of the soil. The rhizosphere contains more gram-negative and denitrifying bacteria than the soil. Bacteria are part of various biogeochemical cycles, such as the nitrogen 
cycle and the carbon cycle. Micromycetes found in the soil are mainly divided into three groups: destructors, mutualists (mycorrhizal fungi) and pathogens. Mycorrhizal fungi are mainly found around the roots of plants, while other groups of micromycetes are found throughout the soil. Micromycetes play an important role in the soil, taking part in the nutrient cycle, water dynamics and disease suppression, which maintains soil health and increases yields. Actinomycetes are a leading group of soil microorganisms that play an important role in the processing of organic matter into the environment. They promote plant growth by improving the availability of nutrients and minerals, synthesizing growth regulators, inhibiting phytopathogens through the synthesis of antibiotics. At the same time, in each of the groups of soil microorganisms there are pathogenic species that can adversely affect the growth of plants and other soil microorganisms, reducing biodiversity $[2,17,18]$. In addition, there is a close correlation between the rhizosphere microbiota and the chemical composition of root exudates. The composition of exudates contains up to $20 \%$ of carbon compounds, $15 \%$ of nitrogen, sugars, organic acids, secondary metabolites and mucus. The chemical composition of plant exudates varies depending from the genotype of plants, phase of development, biotic and abiotic factors action and is regulated by abiotic stressors [19]. It is reported, that plant releases into the rhizosphere from 5 to $40 \%$ of carbon, which is fixed by photosynthesis [20].

The total content of microorganisms in the rhizosphere of phytoplasma-infected plants increased compared to the rhizosphere microbiota of control plants. The total amount of microorganisms that absorb nitrogen from mineral compounds and actinomycetes increased and the total amount of micromycetes decreased in the rhizosphere of phytoplasma-infected plants. It is also known that phytoplasma is an obligate parasite of cells with limited metabolism and requires both carbohydrates and amino acids for its existence [21]. Thus, infected plant has an increased need for nitrogen and phosphorus nutrition, and has lower carbohydrate content in the root secretions. It is known that mycorrhizal fungi enhance the absorption of mineral nutrients by plants (e.g. phosphorus and zinc) in exchange for carbohydrate compounds synthesized by plants in the process of photosynthesis [18]. Therefore, a decrease in total micromycetes count in the case of infection caused by phytoplasma and bacteria may indicate the decrease of carbohydrates amount in the root exudates. The total actinomycetes count increased in plants infected with phytoplasma and bacteria. It is known, that actinomycetes in the rhizosphere of plants are producers of antibiotics. Most likely the increasing of their amount is associated with the changes in the chemical composition of root secretions, which involve the content of stress signal molecules and reduced carbohydrates. It is known that actinomycetes are involved in the carbon cycle and the decomposition of complex organic compounds [18].

It should be noted that the total oligotrophic bacteria count in the rhizosphere of Galega orientalis increased most significantly after infection with phytoplasma.

It is known that oligotrophic microorganisms are characterized by their ability to grow at low concentrations of substrate (nitrogen and carbon in the nano- and picomolar range) and, as a rule, have a higher efficiency of substrate use. Compared to copyotrophic, oligotrophic microorganisms have a higher biomass yield per unit of substrate consumed [2]. These groups of microorganisms are identified mainly at the late stage of succession, when the resources of easily accessible substrate are depleted and found in large quantities under conditions of organic land use [13].

Thus, a significant increase in the number of oligotrophic microorganisms in the rhizosphere of plants in the case of infection with phytoplasma indicates the inhibition of the excretion of nitrogenand carbon-containing compounds in the root excretions of infected plants and evidences the presence of pathological process at the metabolic level. It may also be an indirect acknowledgment of nitrogen-fixing ability reducing of Galega orientalis plants. It should be noted that a similar trend was observed after plants infection with $P$. syringae pv. atrofaciens $\mathrm{D} 13$, but to a much lesser extent. However, plants infection with $P$. syringae isolated from wheat increased the total amount of nitrogen-fixing bacteria in the rhizosphere of Galega orientalis, in contrast with rhizosphere of plant infected with phytoplasma. In the paper of Rudrappa et al. it was proved that 5 days after infected of Arabidopsis plants with P. syringae, isolated from tomatoes stimulated the formation of biofilms of beneficial rhizobacteria $B$. subtilis [19]. It was shown in the paper of Lakshmanan et al. that 
infection of Arabidopsis plants with $P$. syringae pv. tomato DC3000 strain induced the expression of malic acid transporter, which led to the increase of beneficial rhizobacteria Bacillus subtilis FB17 titer. This caused an induced systemic response against the pathogen [22]. Therefore, both total actinomycetes count increased at infection with A. laidlawii and $P$. syringae and total aerobic nitrogen-fixing bacteria count increased at infection with $P$. syringae pv. atrofaciens D13, that is most likely associated with the production of stressinduced metabolites by roots due to a systemic response to infection. Foliar treatment of plants with all experimental solutions of nanochelates led to total microbial count increasing, which probably also indicates a change in the chemical composition of root secretions, its enrichment. In particular, in the paper of Bledsoe et al. the growth of bacterial diversity in the rhizosphere of plants with longterm addition of nutrients was shows. In addition, the rhizosphere of forbs was enriched with diseasesuppressing bacterial taxa, and the rhizosphere of grass was enriched with bacterial taxa associated with complex carbon degradation [20].

However, foliar treatment of plants with these nanochelates had different influence on the microbiota composition. It was established an increase in the total aerobic nitrogen-fixing bacteria count in plants treated with: V (11.5 times), Ge (8.8 times), Se (3.3 times), I-Se (by $9.5 \%$ ); of the total actinomycetes count in plants treated with: $\mathrm{V}$ (11.0 times), Se (11.7 times), Ge (10.1 times), I-Se (by $54.8 \%$ ); of the total micromycetes count in plants treated with: Se (1.6 times), Ge (2 times). The total micromycetes count decreased by $47.9 \%$ after foliar treatment with I-Se and V nanochelates. Moreover, the presence of oligotrophic microorganisms in the rhizosphere decreased after foliar treatment with Se (by $11.1 \%$ ) and V (by $18.8 \%$ ). The total oligotrophic microorganisms count remained at the control level after foliar treatment with Ge nanochelates, while after I-Se treatment it increased significantly - 16.8 times. It should be noted that since oligotrophic microorganisms are able to grow only on depleted substrate, their significant development may be an evidence of important soil microorganisms inhibition, in this regard, its action cannot be considered fully favorable for protecting plants from pathogens.

However, infection with phytoplasma, as well as bacterial pathogens showed significant inhibitory effect on the root system growth, also causing a reduction in the number of nodules on the roots.

Foliar treatment of infected plants with nanochelates reduced the negative effect of infection by these parameters. Thus, the length of the roots at foliar treatment of pathogen-infected plants increased in the next order: $\mathrm{Se}>\mathrm{V}>\mathrm{I}-\mathrm{Se}$ (in the case of phytoplasmosis) and $\mathrm{Ge}>\mathrm{I}-\mathrm{Se}>\mathrm{Se}$ (in the case of bacteriosis). Foliar treatment with $\mathrm{V}$ nanochelates of plants infected with phytoplasma contributed to the growth of shoots. In bacterial infection, foliar treatment of plants with $\mathrm{V}$ and Ge nanochelates contributed to the enhancement of shoot growth. The root nodule count of Galega orientalis increased in the following order: $\mathrm{Se}>\mathrm{V}>\mathrm{Ge}>\mathrm{I}-\mathrm{Se}$ (in phytoplasma-infected plants); $\mathrm{Se}>\mathrm{I}-\mathrm{Se}>\mathrm{Ge}>\mathrm{V}$ (in bacteria-infected plants) compared to infected plants without treatment.

Conclusions. The number of actinomycetes, micromycetes and oligotrophic microorganisms in the rhizosphere of Galega orientalis plants infected with $A$. laidlawii and $P$. syringae increased compared to control plants; this process was associated with changes in the chemical composition of root secretions, probably due to reducing of carbohydrates and the presence of stress signal molecules. Plants infection with these pathogens had different effect on the total amount of aerobic nitrogen-fixing bacteria, the number of which increased in the rhizosphere after infection with $P$. syringae and decreased after infection with A. laidlawii, which may be due to the different chemical composition of the root secretions. Foliar treatment with $\mathrm{Se}, \mathrm{Ge}$ and $\mathrm{V}$ nanochelates had the most favorable influence on the soil microbiota, causing an increase in the total amount of microbial groups, including species capable of disease development inhibiting and participating in the nutrient cycle (aerobic nitrogen-fixing bacteria, actinomycetes, micromycetes). The foliar treatment of plants with I-Se nanochelates can be considered as conditionally favorable due to a significant increase in the number of oligotrophic microorganisms, which indicates the depletion of readily available nutrients in the soil. However, the improvement of root system growth at I-Se foliar treatment of plants affected by both phytoplasma and bacterial pathogen may be a sign of stimulation of the absorptive capacity of roots, which requires further research. 
МІКРОБНИЙ СТАТУС РИЗОСФЕРИ

GALEGA ORIENTALIS 3A

УРАЖЕННЯ ФІТОПАТОГЕНАМИ

ТА ОБРОБКИ НАНОХЕЛАТАМИ

\section{Г.Б. Гулясва ${ }^{1}$,.П. Токовенко ${ }^{1}$, Л.А. Пасічник ${ }^{1}$ В.П. Патика ${ }^{1}$, С.М. Горбатюк ${ }^{2}$}

${ }^{1}$ Інститут мікробіології і вірусології ім. Д.К. Заболотного НАН Украӥни, вул. Академіка Заболотного, 154, Київ, 03143, Україна

${ }^{2}$ Вінницький національний медичний університет імені М. І. Пирогова, вул. Пирогова, 56, Вінниия, 21018, Україна

\section{Резюме}

Відомо, що співвідношення основних груп мікроорганізмів, з яких складається мікробіоценоз визначає біологічну родючість грунту. У зв'язку з цим варто враховувати вплив біологічно активних речовин, в тому числі наночасток та їх похідних, за їх застосування у рослинництві на склад грунтової мікробіоти, іï біорізноманітність. Мета. Метою роботи було дослідження впливу інокуляції рослин Galega orientalis фітопатогенними мікроорганізмами та позакореневої обробки рослин нанохелатами на чисельність основних груп мікроорганізмів у ризосфері грунту. Методи. Acholeplasma laidlawii var. granulum 118 УКМ ВМ-34 культивували на рідкому поживному середовищі CM IMB-72 (pH 7,8) у термостаті за температури $32{ }^{\circ} \mathrm{C}$ впродовж 72 год. Бактерії Pseudomonas syringae pv. atrofaciens Д13 культивували на картопляному агарі за температури 26$28^{\circ} \mathrm{C}$ в термостаті. Для штучного зараження застосовували бактеріальну суспензію щільністю $1 \times 10^{9}$ КУО/мл. Інокуляцію рослин Galega orientalis фітопатогенними штамами мікроорганізмів здійснювали за допомогою суб'епідермальної ін'єкції. Чисельність основних груп мікроорганізмів грунту визначалали методом мікробіологічного посіву грунтової суспензії на тверді поживні середовища і виражали у колоній-утворювальних одиницях (КУО). Для статистичної обробки даних здійснювали розрахунки середнього арифметичного та його стандартної похибки. Результати. Встановлено, що за інфікування фітоплазмою збільшувалась загальна чисельність мікрооорганізмів, актиноміцетів і оліготрофних мікроорганізмів та знижувався вміст мікроміцетів. На відміну від інфікування фітоплазмою за інокуляції рослин P. syringae pv. atrofaciens Д13 спостерігали зростання аеробних азотфіксаторів. Обробка рослин Galega orientalis розчинами нанохелатів впливала на склад мікробіоти у різній мірі. Загальна кількість аеробних азотфіксаторів зростала у послідовності: $\mathrm{V}>\mathrm{Ge}>\mathrm{Se}$, а частка актиноміцетів збільшувалась на варіантах обробки у послідовності: $\mathrm{Se}>\mathrm{V}>\mathrm{Ge}$. Збільшення мікроміцетів відмічали у випадку обробки Ge i Se. Варто відмітити, що найбільш значне підвищення оліготрофних мікроорганізмів спостерігали у варіанті обробки I-Se. Висновки. Інфікування рослин Galega orientalis A. laidlawii i P. syringae спричинювало збільшення в ризосфері рослин актиноміцетів, мікроміцетів і оліготрофних мікроорганізмів, що обумовлено зміною хімічного складу кореневих виділень, ймовірно із вмістом стресових сигнальних молекул i зниженим вмістом вуглеводів. Рослини, інфіковані цими збудниками різнились за впливом на чисельність аеробних азотфіксаторів, кількість яких зростала в ризосфері за інфікування $P$. syringae i зменшувалась за інфікування A. laidlawii, що може бути пов'язане з різним хімічним складом кореневих виділень. Обробка нанохелатами $\mathrm{Se}, \mathrm{Ge} \mathrm{i}$ $\mathrm{V}$ виявилась найбільш сприятливою за впливом на грунтову мікробіоту, спричинюючи зростання чисельності груп мікроорганізмів, серед яких $€$ види, здатні пригнічувати розвиток хвороб і брати участь у круговороті поживних речовин (аеробних азотфіксаторів, актиноміцетів, мікроміцетів). Обробку ж рослин I-Se можна назвати умовно сприятливою за рахунок суттєвого підвищення оліготрофних мікрооргазмів, що свідчить про збіднення грунту на легкодоступні поживні речовини. Проте поліпшення росту кореневої системи при обробці I-Se рослин, уражених як фітоплазмою, так і бактеріальним збудником може бути ознакою стимуляції поглинальної здатності коренів, що потребує додаткових досліджень.

Ключові слова: Galega orientalis, A. laidlawii var. granulum, P. syringae pv. atrofaciens, хелати наночасток, грунтова мікробіота. 
1. Docherty KM, Gutknecht JLM. Soil microbial restoration strategies for promoting climate ready prairie ecosystems. Ecological Applications. 2019; 29(3). https://doi.org/10.1002/ eap. 1858

2. Ho A, Di Lonardo DP, Bodelier PLE. Revisiting life strategy concepts in environmental microbial ecology. FEMS Microbiology Ecology. 2017; 93 (3):1-14. https://doi.org/ 10.1093/femsec/fix006

3. Kertész Á. The global problem of land degradation and desertification. Hungarian Geographical Bulletin. 2009; 58(1):19-31.

4. Rosa Graciele Ferreira da, Casali Carlos Alberto, Bechara Fernando Campanha, Viceli Jéssica Maiara, Moreira Flavia Lima, Guimarães Bruna Schneider, et al. Soil Microbiological Attributes Under Ecological Restoration Technologies in Subtropical Forest. Braz arch biol technol. [Internet]. 2020; 63(spe): e20190651. Available from: 2020. http://dx.doi.org/10.1590/1678-4324-solo-2020190651

5. Kumar BL, Sai Gopal DVR. Effective role of indigenous microorganisms for sustainable environment. Biotech. 2015; 5(6):867-876. doi:10.1007/s13205-015-0293-6

6. Maestre FT, Solé R, Singh BK. Microbial biotechnology as a tool to restore degraded drylands. Microb Biotechnol. 2017; 10(5):12501253. doi:10.1111/1751-7915.12832

7. Peng X, Bruns MA. Cyanobacterial soil surface consortia mediate $\mathrm{N}$ cycle processes in agroecosystems. Front Environ Sci. 2018b; 6:156. https://doi:10.3389/fenvs.2018.00156.

8. Wang CH, Wu L, Wang Z, Alabady MS, Parson D, Molumo Z, et al. Characterizing changes in soil microbiome abundance and diversity due to different cover crop techniques. PLoS ONE. 2020; 15(5):e0232453. https://doi.org/10.1371/journal. pone. 0232453

9. Duhan JS, Kumar R, Kumar N, Kaur P, Nehra K, Duhan S. Nanotechnology: The new perspective in precision agriculture. Biotechnol Rep (Amst). 2017; 15:1-23. doi: https://doi.org/10.1016/j. btre.2017.03.002

10. Chhipa H. Applications of nanotechnology in agriculture. In: Methods in Microbiology. Volker Gurtler, Andrew S. Ball, Sarvesh Soni, editors.
2019; 6(46):115-142. https://doi.org/10.1016/ bs.mim.2019.01.002

11. Usman M, Farooq M, Wakeel A, Nawaz A, Cheema AS, Rehman H, Ashraf I, Sanaullah M. Nanotechnology in agriculture: Current status, challenges and future opportunities. Science of the Total Environment. 2020; 721:137778. https:// doi.org/10.1016/j.scitotenv.2020.137778

12. Liu R, Lal R. Potentials of engineered nanoparticles as fertilizers for increasing agronomic productions. Sci Total Environ. 2015; 514:131139.

13. Volkohon VV, Nadkernychna OV, Tokmakova LM. Eksperymentalna gruntova mikrobiolohiia: monohrafiia; za nauk. red. V.V. Volkohona. K.: Ahrarna nauka; 2010. 464.

14. Peng X, Bruns MA. Cyanobacterial soil surface consortia mediate $\mathrm{N}$ cycle processes in agroecosystems. Front Environ Sci. 2019; 6(JAN):156. https://doi:10.3389/fenvs.2018.00156.

15. Sasse J, Martinoia E, Northen T. Feed Your Friends: Do Plant Exudates Shape the Root Microbiome? Trends and plant science. 2018; 23(1):25-41. https://doi.org/10.1016/j. tplants.2017.09.003

16. Johns C. Living Soils: The Role of Microorganisms in Soil Health. Northern Australia \& Land Care. 2017. https://www.futuredirections.org. $\mathrm{au} /$ publication /living-soils-role-microorganisms-soil-health/

17. Anwar S, Ali B, Sajid I. Screening of Rhizospheric Actinomycetes for Various in-vitro and In-vivo Plant Growth Promoting (PGP) Traits and for Agroactive Compounds. Front Microbiol. 2016; 7(1334):1-11. doi: https://doi.org/10.3389/ fmicb.2016.01334

18. Sapkota A. Microorganisms found in soil with effects and examples. 2020. https://microbenotes. com/microorganisms-in-soil/

19. Rudrappa T, Czymmek KJ, Paré PW, Bais HP. Root-Secreted Malic Acid Recruits Beneficial Soil Bacteria. Plant Physiology. 2008; 148 (3):1547-1556, https://doi.org/10.1104/ pp.108.127613

20. Bledsoe RB, Goodwillie C, Peralta AL. Longterm nutrient enrichment of an oligotrophdominated wetland increases bacterial diver- 
sity in bulk soils and plant rhizospheres. bioRxiv 2020.01.08.899781; doi: 10.1128/msphere. 00035-20

21. Namba S. Molecular and biological properties of phytoplasmas. Proc Jpn Acad Ser B Phys Biol Sci. 2019; 95(7):401-418. doi:10.2183/ pjab. 95.028
22. Lakshmanan V, Kitto SL, Caplan JL, Hsueh Yi-H, Kearns DB, Wu Yu-S, Bais HP. Microbe-associated molecular patterns-triggered root responses mediate beneficial rhizobacterial recruitment in Arabidopsis. Plant Physiol. 2012; 160(3):164261. doi: 10.1104/pp.112.200386.

Received 16.03.2021 